\title{
Salyut-7 (2017)
}

Action, Drama, History, $111 \mathrm{~min}$.

Directed by: KLIM SHIPENKO.

Written by: ALEKSEY CHUPOV, NATALYA MARKULOVA, ALEKSEY SAMOLYOTOV, KLIM SHIPENKO.

Cast: Vladimir Vdovichenkov, Pavel Derevyanko, Aleksandr Samoylenko.

Russia: CTB Film Company, Globus-film, Lemon Films Studio, Telekanal Rossiya, Vita Aktiva.

Language: Russian.

Klim Shipenko's film Salyut-7 is a cinematic amalgam of space action and historical drama. The plot is based on the historical Soyuz T-13 mission, sent to rescue the Soviet space station Salyut-7. In early February 1985, all contact to the space station was lost. The public was scared of an uncontrolled re-entry of the 20 -ton colossus to over populated areas. Due to the continuation of the Cold War in space, the Soviet authorities feared an American seizure of the Salyut-7 and the theft of sensitive military material. A race had begun, and the foundation for a thrilling plot was laid.

As noted by Shipenko during a Q\&A session after the screening of Salyut-7 at the Russian Film Week, the producers decided to make a blockbuster film instead of creating a historical documentary or an arthouse film. Supporting the producers' choice, Shipenko also noted that a blockbuster would allow a big audience to learn about the legendary rescue mission. Lovers of history and arthouse productions should therefore narrow down their expectations. Salyut-7 does not show interviews with Soviet cosmonauts or archive footage. Nor does it have the philosophical depth, the pioneering special effects, and the cultural and aesthetic significance of Stanley Kubrick's 2001: A Space Odyssey (1968). Nor could Salyut-7 be seen in the tradition of great Soviet space movies such as Andrei Tarkovsky's psychological sci-fi drama Solaris (1972). Instead, this is a poor attempt to tell the story of the Soyuz T-13 rescue mission.

Like many other blockbuster and action movies, Salyut-7 follows a clear pattern without many surprises. One life-threatening challenge follows after the other and has to be resolved by two cosmonaut action heroes, be it the skilled docking of the Soyuz T-13 with the Salyut-7 space station, the extreme cold in the latter, or the severe lack of oxygen. During the Q\&A session, Klim Shipenko noted that while all events of the film have occurred, they did so only in "one or another way", meaning that they were not necessarily part of the Soyuz T-13 rescue mission. Although he wants more people to know about the mission's story, he needed "some freedom" for a true blockbuster. Not only were the cosmonauts' surnames changed, but whole elements of the film were actually borrowed from other space missions. Salyut-7 therefore rather resembles a composition of different space missions and uses the story of the Soyuz T-13 mission only as a guiding narrative thread. Shipenko's simultaneous goals of telling the mission's story while 
Reviews: Films

seeking a large audience the inner tension of Salyut-7 can be seen as a natural tension between informing and entertaining. Despite this inner tension, can one at least sit back and enjoy the film?

While the majority of the audience seemed to do so, I could not. In fact, I cannot even recall any original, charming, clever, absorbing or fascinating scene. The actors' performances were monotonous and not particularly authentic or memorable. Not a single monologue or dialogue intrigued me. Not a single joke was funny. Instead, I found the conversations corny and the jokes predictable, just as the relations between the characters or the overdramatised music, which has also distupted the aim to place the audience back into the year 1985. Nonetheless, I would also like to mention one skillful and aesthetically valuable aspect of Salyut-7, namely the attempt to work with real zero-gravity. In contrast to the film Gravity (2013), Salyut-7 respects the laws of physics. Although one can criticize this film in many ways, Salyut-7 has nevertheless introduced me to the story of the Soyuz T-13 rescue mission, even though one cannot fully trust Shipenko's version of events.

\section{PHILLIP LUGMAYR}

University College London

This work is licensed under the Creative Commons Attribution-NonCommercial-ShareAlike 3.0 Unported License. To view a copy of this license, visit http://creativecommons.org/licenses/bync-sa/3.0/ or send a letter to Creative Commons, PO Box 1866, Mountain View, CA 94042, USA. 